論文

\author{
인장 하중을 받는 무한 고체에 포함된 다수의 \\ 이방성 함유체 문제 해석을 위한 체적 적분방정식법
}

이정기

\title{
Volume Integral Equation Method for Multiple Anisotropic Inclusion Problems in an Infinite Solid under Uniaxial Tension
}

\author{
Jung-Ki Lee
}

\begin{abstract}
A volume integral equation method (VIEM) is introduced for the solution of elastostatic problems in an unbounded isotropic elastic solids containing interacting multiple anisotropic inclusions subject to remote uniaxial tension. The method is applied to two-dimensional problems involving long parallel cylindrical inclusions. A detailed analysis of stress field at the interface between the matrix and the central inclusion is carried out for square and hexagonal packing of the inclusions. Effects of the number of anisotropic inclusions and various fiber volume fractions on the stress field at the interface between the matrix and the central inclusion are also investigated in detail. The accuracy of the method is validated by solving the single inclusion problem for which solutions are available in the literature.
\end{abstract}

\section{초 록}

체적 적분방정식법(Volume Integral Equation Method)이라는 새로운 수치해석 방법을 이용하여, 서로 상호작용을 하는 이 방성 함유체를 포함하는 등방성 무한고체가 정적 인장하중을 받을 때 무한고체 내부에 발생하는 응력분포 해석을 매우 효과 적으로 수행하였다. 즉, 등방성 기지에 다수의 이방성 함유체가 1) 정사각형 배열 형태 또는 2) 정육각형 배열 형태로 포함되 어 있는 경우에 대하여, 다양한 함유체의 체적비에 대하여, 중앙에 위치한 이방성 함유체와 등방성 기지의 경계면에서의 인장 응력 분포의 변화를 구체적으로 조사하였다. 또한, 단일의 이방성 함유체에 대한 체적 적분방정식법을 이용한 해와 해석해를 비교해 봄으로서, 체적 적분방정식법을 이용하여 구한 해의 정확도를 검증하였다.

Key Words : 체적 적분방정식법(Volume Integral Equation Method), 이방성 함유체(Anisotropic Inclusion), 섬유 체적분율 (Fiber Volume Fraction), 복합 재료(Composite Materials)

\section{1. 서 론}

복합재료의 구성물들은 일반적으로 등방성 재료로 이루어 진다. 그러나, 기존의 금속재료에 비하여 비강성, 비강도 및 내열성, 내마모성 등이 뛰어나 항공분야에 사용되고 있는 금 속기지 복합재료에서는 $\mathrm{Ti}$ 기지는 등방성 재료로 이루어지지
만 $\mathrm{SiC}$ 섬유는 강한 이방성 재료로 이루어진다. 따라서, 복합재료에서의 파손 메카니즘을 정확히 예측하기 위해서는, 등방성 함유체 또는 이방성 함유체가 포함된 등방 성 무한고체에서의 탄성 해석이 필요하다.

인장하중을 받을 때, 단일 또는 다수의 등방성 또는 이방 성 함유체를 포함하는 무한 고체에서의 탄성해석에 관한 연

* 홍익대학교 기계정보공학과, 교신저자(E-mail:inq3jk1@wow.hongik.ac.kr) 
구는 Eshelby[1], Hashin[2], Yang과 Chou[3], Achenbach와 Zhu[4], Christensen[5], Nimmer 외(et al.)[6], 그리고 많은 연 구자들[7-13]에 의하여 연구되었다.

본 논문에서는, 체적 적분방정식법(Volume Integral Equation Method)이라는 새로운 수치해석 방법을 이용하여, 서로 상호 작용을 하는 이방성 함유체를 포함하는 등방성 무한고체가 정적 인장하중을 받을 때 무한고체 내부에 발생하는 응력분 포 해석을 매우 효과적으로 수행하였다. 즉, 등방성 기지에 다수의, 비교적 간단한 형태의 이방성을 나타내는, 직교 이방 성 함유체가 1) 정사각형 배열 형태 또는 2) 정육각형 배열 형태로 포함되어 있는 경우에 함유체의 체적비(c)가 0.20 부터 0.50 까지 0.05 만큼씩 증가할 때, 중앙에 위치한 직교 이방성 함유체와 등방성 기지의 경계면에서의 인장응력 분포의 변화 를 구체적으로 조사하였다.

\section{2. 체적 적분방정식법(VIEM)}

Fig. 1은 재료특성이 다른 다양한 형태를 갖는 다수의 등 방성 또는 이방성 함유체를 포함하는 무한고체가 무한하중을 받는 일반적인 탄성정역학 문제를 나타낸다. 여기서, 무한하 중이란 무한원방에서 작용하는 하중을 나타낸다.

Fig. 1에서, 기지(matrix)는 무한공간을 차지하는 균일한 등 방성 재료로 이루어지고, 함유체들은 기지와 다른 등방성 또

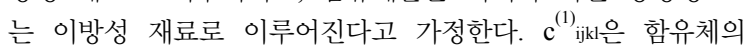
탄성상수를 나타내고, $\mathrm{c}^{(2)} \mathrm{ijkl}_{\mathrm{j} l}$ 는 기지의 탄성상수를 나타낸다. 함유체들과 기지 사이의 경계면은 변위와 표면력 벡터(traction vector)의 연속성을 보장하는 완전결합이라고 가정한다.

Mal과 Knopoff[14]와 Lee와 Mal[8]은 다수의 등방성 또는 이방성 함유체를 포함하는 무한고체 내부의 임의 위치에서의 변위 벡터 $\mathrm{u}_{\mathrm{m}}(\mathrm{x})$ 가

$$
u_{m}(\boldsymbol{x})=u_{m}^{o}(\boldsymbol{x})-\int_{V} \delta c_{i j k l} g_{i, j}^{m}(\boldsymbol{\xi}, \boldsymbol{x}) u_{k, l}(\boldsymbol{\xi}) d \boldsymbol{\xi}
$$

의 방정식을 만족함을 보였다. 식 (1)에서 적분은 전체 무한 공간에 대해서 이루어지고, $\delta \mathrm{c} \mathrm{j}$ jkl $=\mathrm{c}^{(1)}{ }_{\mathrm{j} \mathrm{jkl}}-\mathrm{c}^{(2)}{ }_{\mathrm{ijkl}}$ 이며 등방성 또는 이방성 함유체와 등방성 기지 사이의 탄성상수의 차 이를 나타낸다. $\mathrm{u}_{\mathrm{m}}^{\mathrm{o}}(\mathbf{x})$ 는 무한 하중에 대한 변위를 나타내 며, $\mathrm{gi}_{\mathrm{i}}^{\mathrm{m}}(\xi, \mathbf{x})$ 은 등방성 무한기지에서의 탄성정역학 Green 함 수이다. 즉, $\mathrm{gi}^{\mathrm{m}}(\xi, \mathbf{x})$ 은 등방성 무한기지의 $\mathrm{x}$ 에서 $\mathrm{m}$ 방향으로 작용하는 단위 집중하중 $\mathbf{e}_{\mathrm{m}}$ 때문에 $\xi$ 에서 발생하게 되는 변 위 벡터의 i방향 성분을 나타낸다. 식 (1)에서 합의 규약과 콤마 표기법이 사용되었으며, 미분은 적분변수 $\xi_{\mathrm{i}}$ 에 관해서 행해진다. 여기서, $\delta \mathrm{c}_{\mathrm{cj} j \mathrm{kl}}$ 가 함유체 내부에서만 0 이 아니므로, 피 적분함수(integrand)는 함유체 외부의 무한공간에서는 0 이 된다는 사실을 주목해야 한다[8].

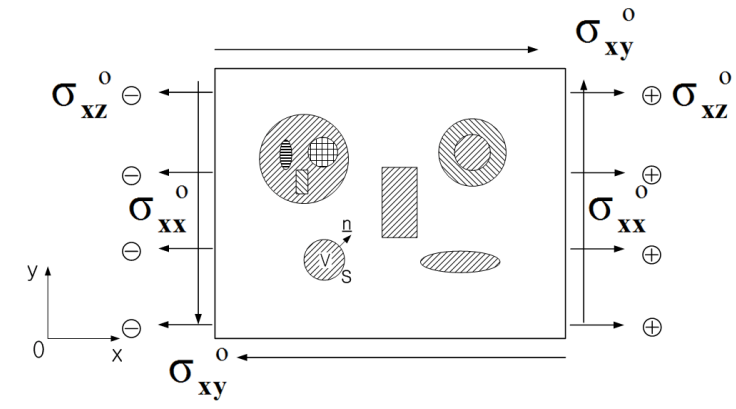

Fig. 1 Geometry of the general elastostatic problem.

만약 $\mathrm{x}$ 가 함유체 내부에 속하면, 식 (1)은 함유체 내부에 서의 미정 변위 벡터 $\mathrm{u}(\mathrm{x})$ 에 관한 적분-미분 방정식(integrodifferential equation)이 된다. 따라서, 임의의 형상을 갖는 단 일의 함유체라 할지라도, 식 (1)의 해를 해석적으로 구한다는 것은 매우 어려운 문제가 된다. 그러므로, 함유체 내부를 표 준의 유한요소들을 사용해서 요소 분할하여 함유체 내부에서 의 $\mathrm{u}(\mathrm{x})$ 를 수치해석 방법으로 결정하는 체적 적분방정식법이 Lee와 $\mathrm{Mal}[8,15]$ 에 의하여 개발되었다. 일단, 함유체 내부에 서의 $\mathrm{u}(\mathrm{x})$ 가 결정되면, 함유체 내부에서의 변형률 및 응력을 계산할 수 있고, 또한 함유체 외부에서의 변위, 변형률 및 응력도 식 (1)의 적분 값을 구함으로써 별다른 어려움없이 계산할 수 있다. 식 (1)에서 $\mathrm{gi}^{\mathrm{m}}$ 은 등방성 무한기지에서의 탄 성정역학 Green 함수이므로, 비록 함유체가 이방성 재료로 이루어진다 할지라도, 체적 적분방정식법에서는 이방성 함유 체에서의 Green 함수를 필요로 하지 않는다는 장점이 있다. 그런데, 일반적으로 이방성 재료에서의 Green 함수는 등방성 재료의 경우와 비교해 볼 때 복잡한 형태로 나타나며, 특히, 탄성동역학 문제에서는 이방성 재료에서의 Green 함수를 구 하는 것이 매우 어려운 것으로 알려져 있다[16].

등방성 무한기지에 다수의 등방성 함유체가 포함된 무한 고체에서의 일반적인 탄성동역학 및 탄성정역학 문제를 해석 하기 위한 체적 적분방정식법에 대한 자세한 기술은 Lee와 $\mathrm{Mal}[8,15]$ 에 잘 나타나 있다. 특히, 복합재료 분야의 전공서 적 가운데 하나인 "Micromechanics of heterogeneous materials"[17]의 '4.3절 Volume Integral Equation Method'에 탄성정역학 문제를 해석하기 위한 체적 적분방정식법에 대한 자세한 설명이 나와 있다.

\section{3. 다수의 직교 이방성 함유체 문제}

Fig. 2에 있는 다수의 직교 이방성 함유체가 등방성 기지에 포함되어 있는 무한고체가 무한 인장하중을 받는 경우를, 평면 변형률 문제로 가정하여, 고찰해 본다. 다수의 함유체의 상호 작용을 조사하기 위하여, 함유체의 체적비(c)가 0.20 부터 0.50 까지 




Fig. 2 Multiple orthotropic cylindrical inclusions in unbounded isotropic matrix under unifom remote tensile loading.

0.05 만큼씩 증가할 때, 함유체의 개수를 늘려가면서, 중앙에 위치한 함유체에서의 응력분포의 변화를 조사하였다. 이 경우 는 체적 적분방정식법이 최적의 수치해석 방법임을 알 수 있 다[8,17]. 왜냐하면, 1) 경계요소법과 달리, 모든 경계면에서의 연속 조건이 자동적으로 만족하고, 직교 이방성 재료에 대한 Green함수를 필요로 하지 않는다는 장점이 있으며, 함유체 내 부를 유한요소를 사용하여 요소 분할하므로 임의 형상을 갖는 함유체를 해석할 때 도 전혀 어려움이 없게 되며, 2) 유한요 소법과 달리, 무한공간을 이루고 있는 기지는 요소분할할 필 요가 없이, 함유체 내부만을 요소분할하면 되기 때문이다. 특 히, 3) 함유체의 체적비가 변화할 때, 기지를 요소분할할 필요 가 없이 함유체의 위치만 변경하면 되므로, 체적 적분방정식 법 모델을 매우 효율적으로 변경할 수 있게 된다.

\section{1 등방성 무한 기지에서의 탄성정역학 Green 함수}

식 (1)에서 등방성 무한기지에 대한 Green 함수[18]는 다 음과 같이 주어진다.

$$
g_{\alpha}^{\beta}=\frac{\lambda+\mu}{4 \pi \mu(\lambda+2 \mu)}\left[-\frac{\lambda+3 \mu}{\lambda+\mu} \operatorname{lnr} \delta_{\alpha \beta}+r_{, \alpha} r_{, \beta}\right]
$$

여기서, $\mathrm{r}=|\mathrm{x}-\xi|, \mathrm{a}, \beta=1,2$ 그리고 $\lambda, \mu$ 는 등방성 무한기지에서의 Lamé 상수를 나타낸다.

\section{2 다수의 직교 이방성 함유체의 배열이 정사각형 (square) 형태일 때}

다수의 직교 이방성 함유체가 정사각형 형태로 등방성 기 지에 포함되어 있는 무한고체가 무한 인장하중을 받는 경우 를, 평면 변형률 문제로 가정하여, 고찰해 본다.

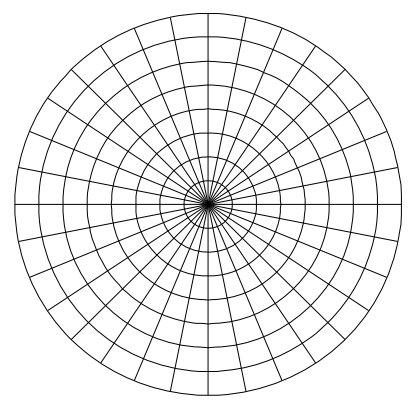

Fig. 3 A typical discretized model in the volume integral equation method.

Table 1 Material properties of the isotropic matrix and the orthotropic inclusion for the elastostatic problems

\begin{tabular}{c|c|c}
\hline \hline (Unit: GPa) & Isotropic Matrix & Orthotropic Inclusion \\
\hline$\lambda$ & 67.34 & - \\
\hline$\mu$ & 37.88 & - \\
\hline $\mathrm{c}_{11}$ & 143.10 & 279.08 \\
\hline $\mathrm{c}_{12}$ & 67.34 & 7.80 \\
\hline $\mathrm{c}_{22}$ & 143.10 & 30.56 \\
\hline $\mathrm{c}_{66}$ & 37.88 & 11.80 \\
\hline \hline
\end{tabular}

Table 2 Fiber separation distances according to different fiber volume fractions

\begin{tabular}{c|c|c}
\hline \hline $\begin{array}{c}\text { Fiber } \\
\text { volume } \\
\text { fraction } \\
\text { (c) }\end{array}$ & Fiber separation distance / Radius of inclusion $(\mathrm{d} / \mathrm{a})$ \\
\cline { 2 - 3 } & Square array & Hexagonal array \\
\hline 0.20 & 3.9633 & 4.2589 \\
\hline 0.25 & 3.5449 & 3.8093 \\
\hline 0.30 & 3.2360 & 3.4774 \\
\hline 0.35 & 2.9960 & 3.2194 \\
\hline 0.40 & 2.8025 & 3.0115 \\
\hline 0.45 & 2.6422 & 2.8392 \\
\hline 0.50 & 2.5066 & 2.6935 \\
\hline \hline
\end{tabular}

우선, 체적 적분방정식법을 이용한 해의 정확도를 검증하 기 위하여, 단일의 직교 이방성 함유체가 등방성 기지에 포 함되어 있는 경우에 직교 이방성 함유체 내부에서의 응력분 포를 조사하였다. 다음에, 다수의 직교 이방성 함유체의 상호 작용을 조사하기 위하여, 함유체의 체적비(c)가 0.20 부터 0.50 까지 0.05 만큼씩 증가할 때, 함유체의 개수를 a) 9 개, b) 25 개, c) 49 개로 늘려가면서, 중앙에 위치한 함유체에서의 응 력분포의 변화를 조사하였다. 직교 이방성 함유체와 등방성 기지의 물질 특성치는 Table 1에 나타나 있으며, 직교 이방 성 함유체의 $\mathrm{c} 11$ 이 등방성 기지의 $\mathrm{c} 11$ 보다 큰 경우를 고려해 보았다. Table 2는 함유체의 체적비에 따라 달라지는 함유체 사이의 거리/함유체의 반지름 $(\mathrm{d} / \mathrm{a})$ 를 나타낸다. 예를 들어, 함 유체의 체적비(c)가 0.35 인 경우에, 함유체 사이의 거리(d)는 $2.9960 \mathrm{a}$ 가 된다. 여기서, a는 함유체의 반지름을 나타낸다. 


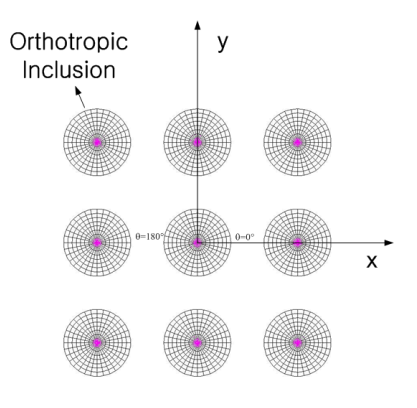

VIEM

Fig. 4 A typical discretized model in the volume integral equation method.

Table 3 Nomalized tensile stress component $\left(\sigma_{x x} / \sigma_{x x}{ }^{9}\right)$ within the orthotropic cylindrical inclusion due to unifom remote tensile loading $\left(\sigma_{x x}{ }^{\circ}\right)$

\begin{tabular}{c|c}
\hline \hline & $\begin{array}{c}\text { Normalized tensile stress component } \\
\text { inside the orthotropic inclusion }\end{array}$ \\
\hline Exact solution & 1.2388 \\
\hline VIEM & 1.2389 (Average) \\
\hline \hline
\end{tabular}

Table 4 Nomalized tensile stress component $\left(\sigma_{x x} / \sigma_{x x}{ }^{0}\right)$ at the interface between the matrix and the central inclusion for models containing square anay of 9,25 and 49 onthotropic inclusions due to unifom remote tensile loading $\left(\sigma_{x x}\right)^{0}$

\begin{tabular}{|c|c|c|c|c|}
\hline \multirow{2}{*}{$\begin{array}{c}\text { Fiber } \\
\text { Volume } \\
\text { Fraction } \\
\text { (c) }\end{array}$} & \multirow{2}{*}{$\begin{array}{c}\text { Number } \\
\text { of } \\
\text { Inclusions }\end{array}$} & \multicolumn{3}{|c|}{ Location } \\
\hline & & $\theta=0^{\circ}$ & $\theta=45^{\circ}$ & $\theta=90^{\circ}$ \\
\hline \multirow{3}{*}{0.20} & 9 & 1.29115 & 1.26047 & 1.25322 \\
\hline & 25 & 1.29342 & 1.26348 & 1.25794 \\
\hline & 49 & 1.29321 & 1.26093 & 1.25250 \\
\hline \multirow{3}{*}{0.25} & 9 & 1.30443 & 1.25495 & 1.24610 \\
\hline & 25 & 1.30717 & 1.25512 & 1.24474 \\
\hline & 49 & 1.30723 & 1.25486 & 1.24417 \\
\hline \multirow{3}{*}{0.30} & 9 & 1.31831 & 1.24510 & 1.23362 \\
\hline & 25 & 1.32212 & 1.24455 & 1.23093 \\
\hline & 49 & 1.32421 & 1.24593 & 1.23239 \\
\hline \multirow{3}{*}{0.35} & 9 & 1.33204 & 1.23163 & 1.21457 \\
\hline & 25 & 1.33926 & 1.23182 & 1.21316 \\
\hline & 49 & 1.33838 & 1.23113 & 1.21162 \\
\hline \multirow{3}{*}{0.40} & 9 & 1.34638 & 1.21623 & 1.18877 \\
\hline & 25 & 1.35430 & 1.21388 & 1.18353 \\
\hline & 49 & 1.35440 & 1.21368 & 1.18150 \\
\hline \multirow{3}{*}{0.45} & 9 & 1.35927 & 1.19758 & 1.15017 \\
\hline & 25 & 1.36953 & 1.19309 & 1.14236 \\
\hline & 49 & 1.37105 & 1.19276 & 1.14078 \\
\hline \multirow{3}{*}{0.50} & 9 & 1.37073 & 1.17657 & 1.09639 \\
\hline & 25 & 1.38501 & 1.17040 & 1.08764 \\
\hline & 49 & 1.38626 & 1.16963 & 1.08579 \\
\hline
\end{tabular}

Fig. 3은 체적 적분방정식법에 사용된 대표적인 분할된 모 델[19]의 예를 나타내며, 함유체를 각각 256개의 표준의 8-절 점 사각형 및 6-절점 삼각형 유한요소를 사용하여 분할하였다.

Table 3은 등방성 기지와 원형 단면을 갖는 실린더 형태의

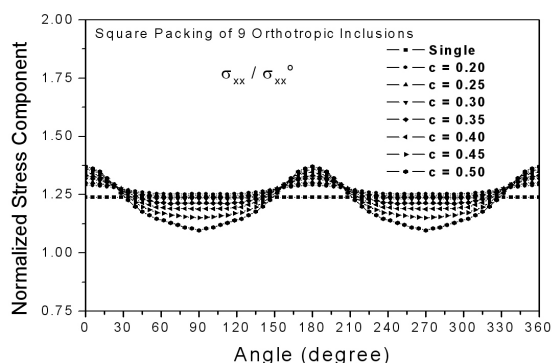

(a)

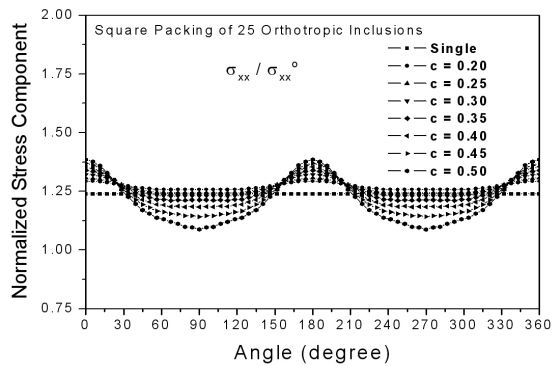

(b)

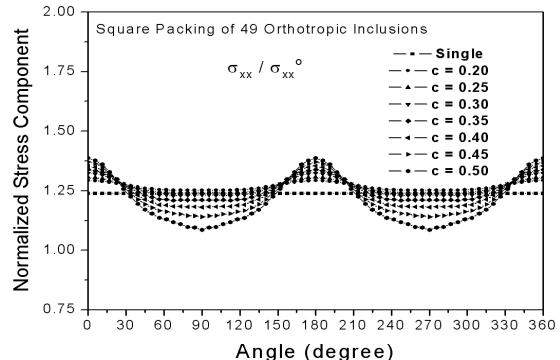

(c)

Fig. 5 Nomalized tensile stress component $\left(\sigma x x / \sigma x x^{0}\right)$ at the interface between the central orthotropic inclusion and the isotropic matrix under uniform remote tensile loading $\left(\sigma_{x x}{ }^{0}\right)$.

단일의 직교 이방성 함유체로 이루어진 무한고체가 무한 인장 하중을 받을 때 함유체 내부에 발생하는 규준화된 인장응력 성분 $\left(\sigma \mathrm{xx} / \mathrm{\sigma xx}{ }^{0}\right)$ 에 대한 체적 적분방정식법의 해와 해석해[3,20]와의 비 교를 나타낸다. 이때, 실린더 형태의 직교 이방성 함유체 내부에 서의 인장응력 성분은 일정한 값을 갖게 된다[3,20,21,22]. 체적 적분방정식법의 해와 해석해가 서로 잘 일치함을 알 수 있다.

다음으로, Fig. 4는 다수의 직교 이방성 함유체의 상호작용 을 조사하기 위하여, 체적 적분방정식법에 사용된 대표적인 분 할된 모델[19]의 예를 나타내며, 각각의 함유체 내부를 각각 256 개의 표준의 8-절점 사각형 및 6-절점 삼각형 유한요소를 사용하여 분할하였다.

Fig. 5 는 서로 다른 함유체의 체적비에 대하여, 서로 다른 개 수의 함유체가 포함되어 있을 때, 중앙에 위치한 직교 이방성 함유체와 등방성 기지의 경계면에서의 규준화된 인장응력 성분 


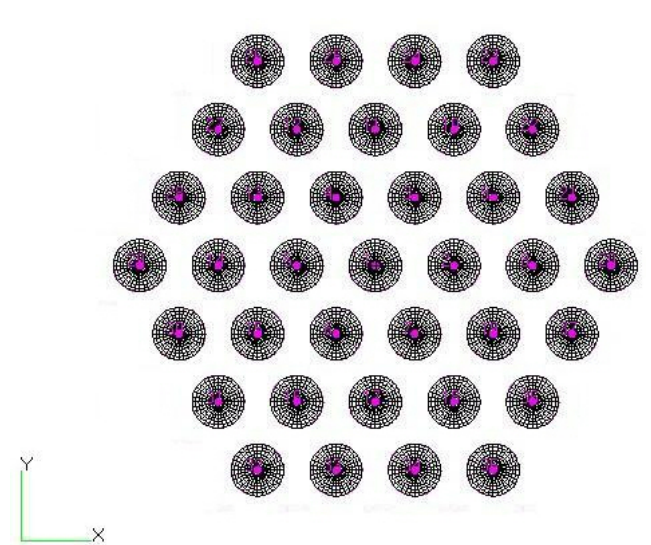

Fig. 6 A typical discretized model in the volume integral equation method for hexagonal inclusion packing amay.

$(\sigma x x / \sigma x x)$ 을 나타낸다 $\left(\Theta=0^{\circ} \sim 360^{\circ}\right)$. 동일한 함유체의 체적비 에 대하여, 직교 이방성 함유체의 개수가 증가하여도 규준화된 인장응력 성분 $\left(\sigma \mathrm{xx} / \sigma_{\mathrm{xx}}{ }^{\circ}\right)$ 이 크게 변하지 않는 것을 볼 수 있다. 그러나, 함유체의 체적비가 증가함에 따라서, 규준화된 인장응 력 성분 $\left(\sigma x x / \sigma x x^{0}\right)$ 이 크게 변하는 것을 볼 수 있다. 그 이유는, 함유체의 체적비가 증가함에 따라서, 중앙에 위치한 함유체와 주변에 있는 함유체들 사이의 상호작용이 커지기 때문으로, Fig. 5에 나와 있는 체적 적분방정법을 이용하여 구한 해를 Table 4에 구체적인 수치들로 정리함으로써, 다른 연구자들이 다른 다양한 방법들을 사용하여 구한 해들의 정확도를 검증할 때 벤치마킹(benchmark)할 수 있도록 하였다.

\section{3 다수의 직교 이방성 함유체의 배열이 정육각형 (hexagon) 형태일 때}

다음에는, 다수의 직교 이방성 함유체가 정육각형 형태로 등 방성 기지에 포함되어 있는 무한고체가 무한 인장하중을 받는 경우를, 평면 변형률 문제로 가정하여, 고찰해 본다.

다수의 함유체의 상호작용을 조사하기 위하여, 함유체의 체적비(c)가 0.20 부터 0.50 까지 0.05 만큼씩 증가할 때, 함유체 의 개수를 a) 7 개, b) 19 개, c) 37 개로 늘려가면서, 중앙에 위치한 함유체에서의 응력분포의 변화를 조사하였다. 직교 이방성 함유체와 등방성 기지의 물질 특성치는 Table 1에 나 타나 있다. Table 2는 함유체의 체적비에 따라 달라지는 함 유체 사이의 거리/함유체의 반지름 $(\mathrm{d} / \mathrm{a})$ 를 나타낸다. 예를 들 어, 함유체의 체적비(c)가 0.40 인 경우에, 함유체 사이의 거 리(d)는 $3.0115 \mathrm{a}$ 가 된다. 여기서, $\mathrm{a}$ 는 함유체의 반지름을 나타낸다. Fig. 6은 다수의 함유체의 상호작용을 조사하기 위하여, 체적 적분방정식법에 사용된 대표적인 분할된 모 델[19]의 예를 나타내며, 각각의 함유체 내부를 각각 256 개의 표준의 8-절점 사각형 및 6-절점 삼각형 유한요소를 사용하여 분할하였다.

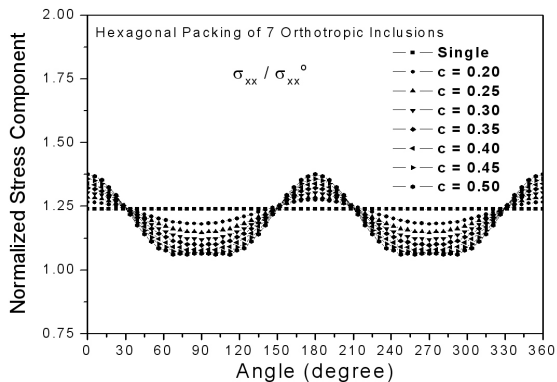

(a)



(b)

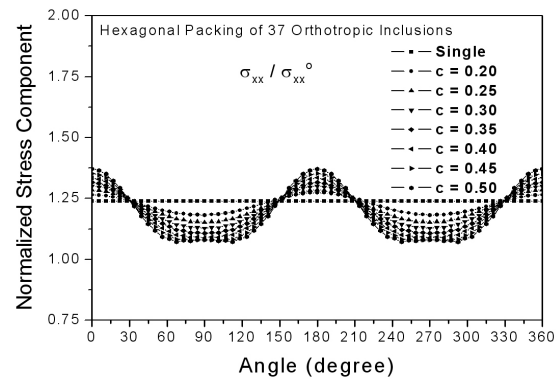

(c)

Fig. 7 Nomalized tensile stress component $\left(\sigma_{x x} / \sigma_{x x}{ }^{0}\right)$ at the interface between the central orthotropic inclusion and the isotropic

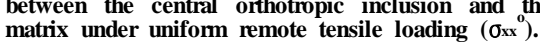

Fig. 7은 서로 다른 함유체의 체적비에 대하여, 서로 다른 개 수의 함유체가 포함되어 있을 때, 중앙에 위치한 직교 이방성 함유체와 등방성 기지의 경계면에서의 규준화된 인장응력 성분 $\left(\sigma x x / \sigma_{x x}{ }^{0}\right)$ 을 나타낸다 $\left(\Theta=0^{\circ} \sim 360^{\circ}\right)$. 이번에도, 동일한 함유체 의 체적비에 대하여, 직교 이방성 함유체의 개수가 증가하여도 규준화된 인장응력 성분( $\left(\mathrm{xx}_{\mathrm{xx}} / \mathrm{\sigma xx}^{\circ}\right)$ 이 크게 변하지 않는 것을 볼 수 있다. 그러나, 함유체의 체적비가 증가함에 따라서, 규준화 된 인장응력 성분 $\left(\sigma_{x x} / \sigma_{x x}{ }^{0}\right)$ 이 크게 변하는 것을 볼 수 있다. 그 이유는, 함유체의 체적비가 증가함에 따라서, 중앙에 위치한 함 유체와 주변에 있는 함유체들 사이의 상호작용이 커지기 때문 으로 판단된다.

Fig. 7에 나와 있는 체적 적분방정식법을 이용하여 구한 해를 Table 5에 구체적인 수치들로 정리함으로써, 다른 연구자들이 
Table 5 Nomalized tensile stress component $\left.\left(\sigma_{x x} / \sigma_{x x}\right)^{0}\right)$ at the interface between the max and between the matrix and the central inclusion for models inclusions hex

\begin{tabular}{|c|c|c|c|c|}
\hline \multirow{2}{*}{$\begin{array}{c}\text { Fiber } \\
\text { Volume } \\
\text { Fraction } \\
\text { (c) }\end{array}$} & \multirow{2}{*}{$\begin{array}{c}\text { Number } \\
\text { of } \\
\text { Inclusions }\end{array}$} & \multicolumn{3}{|c|}{ Location } \\
\hline & & $\theta=0^{\circ}$ & $\theta=45^{\circ}$ & $\theta=90^{\circ}$ \\
\hline \multirow{3}{*}{0.20} & 7 & 1.26604 & 1.21766 & 1.18057 \\
\hline & 19 & 1.26415 & 1.21679 & 1.18090 \\
\hline & 37 & 1.26511 & 1.21754 & 1.18121 \\
\hline \multirow{3}{*}{0.25} & 7 & 1.28610 & 1.20884 & 1.14720 \\
\hline & 19 & 1.28452 & 1.20991 & 1.15152 \\
\hline & 37 & 1.28570 & 1.21079 & 1.15208 \\
\hline \multirow{3}{*}{0.30} & 7 & 1.30272 & 1.19695 & 1.12023 \\
\hline & 19 & 1.29940 & 1.19765 & 1.12592 \\
\hline & 37 & 1.30018 & 1.19905 & 1.12762 \\
\hline \multirow{3}{*}{0.35} & 7 & 1.32131 & 1.18485 & 1.09750 \\
\hline & 19 & 1.31744 & 1.18551 & 1.10393 \\
\hline & 37 & 1.31622 & 1.18684 & 1.10669 \\
\hline \multirow{3}{*}{0.40} & 7 & 1.33950 & 1.17023 & 1.07776 \\
\hline & 19 & 1.33541 & 1.17188 & 1.08644 \\
\hline & 37 & 1.33542 & 1.17359 & 1.08928 \\
\hline \multirow{3}{*}{0.45} & 7 & 1.35748 & 1.15576 & 1.06672 \\
\hline & 19 & 1.35469 & 1.15766 & 1.07632 \\
\hline & 37 & 1.35352 & 1.15959 & 1.07977 \\
\hline \multirow{3}{*}{0.50} & 7 & 1.37446 & 1.14079 & 1.06474 \\
\hline & 19 & 1.37373 & 1.14317 & 1.07685 \\
\hline & 37 & 1.37245 & 1.14558 & 1.08063 \\
\hline
\end{tabular}

다른 다양한 방법들을 사용하여 구한 해들의 정확도를 검증할 때 벤치마킹(benchmark)할 수 있도록 하였다.

\section{4. 결 론}

본 논문에서는 이방성 함유체의 배열이 복합재료의 응 력에 미치는 영향에 대하여 조사하기 위하여, 체적 적분 방정식법이라는 새로운 수치해석 방법을 적용하여, 등방 성 무한기지에 다수의 직교 이방성 함유체가 포함된 무한 고체가 정적 무한하중을 받을 때 복합재료에 발생하는 응 력분포에 관한 해석을 수행하였다.

첫째로, 등방성 기지에 다수의 직교 이방성 함유체가 1) 정사각형 배열 형태, 2) 정육각형 배열 형태로 포함되어 있 는 경우에 대하여 고찰해 보았다. 직교 이방성 함유체의 배 열이 정사각형 또는 정육각형 형태인 각각의 경우에, 함유체 의 체적비가 0.20 부터 0.50 까지 0.05 만큼씩 증가할 때, 중앙 에 위치한 직교 이방성 함유체와 등방성 기지의 경계면에서 의 인장응력 분포의 변화를 조사하였다.

둘째로, 본 논문에서 체적 적분방정식법을 이용하여 구한 해를 그림과 표로 정리함으로써, 다른 연구자들이 다른 다양 한 방법들을 사용하여 구한 해들의 정확도를 검증할 때 벤치 마킹(benchmark)할 수 있도록 하였다.

\section{후 기}

본 연구는 중소기업청 2009년도 산학연협력 기업부설연구 소 설치지원 사업에서 지원하는 연구과제로 수행된 것이며, 지원에 대해 진심으로 감사드립니다.

\section{참고문헌}

1) Eshelby, J.D., "The Determination of the Elastic Field of an Ellipsoidal Inclusion, and Related Problems," Proceedings of the Royal Society of London, Series A, A241, 1957, pp. 376-396.

2) Hashin, Z., Theory of Fiber Reinforced Materials, NASA CR-1974, 1972.

3) Yang, H.C. and Chou, Y.T., "Generalized Plane Problems of Elastic Inclusions in Anisotropic Solids," Transactions of the ASME, Journal of Applied Mechanics, Vol. 43, 1976 (Sep.), pp. 424-430.

4) Achenbach, J.D. and Zhu, H., "Effect of Interphases on Micro and Macromechanical Behavior of Hexagonal-Array Fiber Composites," Transactions of ASME, Journal of Applied Mechanics, Vol. 57, 1990, pp. 956-963.

5) Christensen, R.M., Mechanics of Composite Materials, Krieger Pub. Co., Florida, 1991.

6) Nimmer, R.P., Bankert, R.J., Russel, E.S., Smith, G.A. and Wright, P.K., "Micromechanical Modeling of Fiber/Matrix Interface Effects in Transversely Loaded SiC/Ti-6-4 Metal Matrix Composites," Journal of Composites Technology \& Research, Vol. 13, 1991, pp. 3-13.

7) Zahl, D.B. and Schmauder, S., "Transverse Strength of Continuous Fiber Metal Matrix Composites," Computational Materials Science, Vol. 3, 1994, pp. 293-299.

8) Lee, J.K. and Mal, A.K., "A Volume Integral Equation Technique for Multiple Inclusion and Crack Interaction Problems," Transactions of the ASME, Journal of Applied Mechanics, Vol. 64, 1997 (Mar.), pp. 23-31.

9) Lee, J. and Mal, A., "Characterization of Matrix Damage in Metal Matrix Composites under Transverse Loads," Computational Mechanics, Vol. 21, 1998, pp. 339-346.

10) Naboulsi, S., "Modeling Transversely Loaded Metal-Matrix Composites," Journal of Composite Materials, Vol. 37, 2003, pp. 55-72.

11) Aghdam, M.M. and Falahatgar, S.R., "Micromechanical Modeling of Interface Damage of Metal Matrix Composites Subjected to Transverse Loading," Composite Structures, Vol. 66, 2004, pp. 415-420. 
12) Lee, J.K., Han, H.D. and Mal, A., "Effects of Anisotropic Fiber Packing on Stresses in Composites," Computer Methods in Applied Mechanics and Engineering, Vol. 195, No. 33-36, 2006, pp. 4544-4556.

13) Ju, J.W. and Ko, Y.F., "Micromechanical Elastoplastic Damage Modeling for Progressive Interfacial Arc Debonding for Fiber Reinforced Composites," International Journal of Damage Mechanics, Vol. 17, 2008, pp. 307-356.

14) Mal, A.K. and Knopoff, L., "Elastic Wave Velocities in Two Component Systems," Journal of the Institute of Mathematics and its Applications, Vol. 3, 1967, pp. 376-387.

15) Lee, J.K. and Mal, A.K., "A Volume Integral Equation Technique for Multiple Scattering Problems in Elastodynamics," Applied Mathematics and Computation, Vol. 67, 1995, pp. 135-159.

16) Lee, K.J. and Mal, A.K., "A Boundary Element Method for Plane Anisotropic Elastic Media," Journal of Applied Mechanics, Vol. 57, 1990, pp. 600-606.

17) Buryachenko, V.A., Micromechanics of Heterogeneous Materials, Springer, New York, 2007.

18) Banerjee, P.K., The Boundary Element Methods in Engineering, McGraw-Hill, England, 1993.

19) PATRAN User's Manual, Version 7.0, MSC/PATRAN, 1998.

20) Hwu, C. and Yen, W.J., "On the Anisotropic Elastic Inclusions in Plane Elastostatics," Transactions of ASME, Journal of Applied Mechanics, Vol. 60, 1993 (Sep.), pp. 626-632.

21) Lee, J.K., Choi, S.J. and Mal, A., "Stress Analysis of an Unbounded Elastic Solid with Orthotropic Inclusions and Voids Using a New Integral Equation Technique," International Journal of Solids and Structures, Vol. 38 (16), 2001, pp. 2789-2802.

22) Mal, A.K. and Singh, S.J., Deformation of Elastic Solids, Prentice Hall, New Jersey, 1991. 